\title{
Fate of Acacia mangium in eucalypt mixed-species plantations during drought conditions in the Congolese coastal plains
}

\author{
Destino de Acacia mangium en plantaciones mixtas con especies de eucaliptos \\ durante condiciones de sequía en las llanuras costeras congoleñas
}

\author{
${\text { Lydie-Stella Koutika }{ }^{\text {a*}} \text {, Louis Mareschal }}^{\text {b }}$, Sonia Rudowsky ${ }^{\text {a }}$ \\ *Corresponding author: ${ }^{a}$ Centre de Recherche sur la Durabilité et la Productivité des Plantations Industrielles (CRDPI), BP 1291, \\ Pointe-Noire, République du Congo, phone: 242-068-133-452, 1s_koutika@yahoo.com, \\ ORCID ID: 0000-0001-8223-3032 / LiveDNA 682.13136 \\ ${ }^{\mathrm{b}}$ CIRAD, UMR 111, Ecologie Fonctionnelle and Biogéochimie des Sols and Agro-écosystèmes, Montpellier, France.
}

\begin{abstract}
SUMMARY
A mixed-species plantation of Acacia mangium (acacia) and Eucalyptus urophilla $x$ grandis (eucalypt) hybrid was established on the Arenosols of the coastal Congolese plains to improve soil fertility and sustain forest plantation productivity. At one year into the second rotation, some of the acacia started to exhibit yellowing and drying of leaves, resulting in the death of the whole tree. One-third of the pure acacias (100A) and the mixed, $50 \%$ acacia and $50 \%$ eucalypt (50A50E) hybrid, exhibited these characteristics five months later. To limit the damage, the acacias were pruned up to 1.30 meters. The acacias were threatened by a dry season that extended two months longer than during the previous year, probably triggered by sandy textured soils and poor soil fertility (nitrogen $<0.07 \%$ in the 0.05 meters). Soil moisture to a depth of 0.15 meters was higher under eucalypt compared to acacia. It appears that the acacia root structure may have been less tolerant to drought conditions compared with the eucalypts, leading to damage of acacias, which was exacerbated by the acacia's young age, poor soil fertility and sandy soil texture. One year after pruning, acacias in both 100A and 50A50E presented a healthier tree structure. Furthermore, no negative impact on aboveground biomass -i.e., wood, bark, leaves and branch- has been recorded at 12 and 24 months.
\end{abstract}

Key words: young plantation, dry season, arenosols, pruning.

\section{RESUMEN}

Plantaciones mixtas de Acacia mangium (acacia) y el híbrido de Eucalyptus urophilla x grandis (eucalipto) se establecieron en Arenosoles de las llanuras costeras congoleñas para mejorar la fertilidad del suelo y mantener la productividad de las plantaciones forestales. Un año después de la segunda rotación, parte de la acacia mostró un color amarillento y el secado de hojas, lo que provocó la muerte de todo el árbol. Un tercio de las acacias puras (100A) y el híbrido mixto, $50 \%$ de acacia y $50 \%$ de eucalipto (50A50E) exhibieron estas características cinco meses después. Para limitar el daño, las acacias fueron podadas hasta 1,3 m. Las acacias se vieron amenazadas por una estación seca que se extendió dos meses más que el año anterior, probablemente desencadenada por los suelos de textura arenosa, y la fertilidad del suelo (nitrógeno $<0,07 \%$ en 0-5 cm). La humedad del suelo a una profundidad de $15 \mathrm{~cm}$ fue mayor bajo eucalipto en comparación con acacia. La estructura de la raíz de acacia pudo haber sido menos tolerante a las condiciones de sequía en comparación con los eucaliptos, lo que ha provocado daños en las acacias, que se han visto agravados por la juventud de la acacia, la fertilidad del suelo y la textura del suelo arenoso. Un año después de la poda, la acacia en 100A y 50A50E presentó estructura de árbol más saludable. Además, no se registró ningún impacto negativo en la biomasa aérea, es decir, madera, corteza, hojas y ramas a los 12 y 24 meses.

Palabras clave: plantación joven, estación seca, arenosoles, poda.

\section{INTRODUCTION}

Acacia mangium Willd. is a fast-growing tree mainly used in forestry for the production of paper and solid wood products and for ecological restoration (Eyles et al. 2008, Coetzee et al. 2011). Its taxonomic name is A. mangium, while its common name is black wattle (English) and brown salwood (Australian standard trade name). Acacia mangium is widely planted and has been cultivated out of its native environment of Australia. It has been introduced into humid tropical lowland plantations of Asia, and can also be found in Latin America (Brazil, Colombia, Costa Rica etc.) and in Central Africa (Republic of Congo, Cameroon, DR Congo etc.). 
The natural distribution of $A$. mangium overlaps the warm and hot tropical climatic zones. In these areas, temperatures are high throughout the year, with the mean maximum hottest month between 31 and $34{ }^{\circ} \mathrm{C}$ and the mean minimum coolest month between 15 and $22{ }^{\circ} \mathrm{C}$. The mean annual rainfall is from 1,500 to $3,000 \mathrm{~mm}$, with summer (January to March) being the wettest period. It prefers well-drained, acidic soils (pH of less than 4.0) of moderate to low fertility and has a vigorous growth rate (Cole et al. 1996). Acacia mangium is able to grow reasonably well in nitrogen poor soil and in areas where competition with other plant species is severe. In part, because of its nitrogen-fixing ability. For example, A. mangium could survive in the Imperata grasslands (Yamashita et al. 2008) or in mixed-species plantations combined with fast growing trees such as eucalypts (Inagaki et al. 2011, Bouillet et al. 2013). Its extensive worldwide introduction in forest plantations established on infertile soils is due not only to the improvement in nitrogen $(\mathrm{N})$ dynamics, but also to soil carbon accretion especially when combined with fast growing species (Binkley et al. 2000, Bouillet et al. 2013, Epron et al. 2013, Koutika et al. 2014). No regarding the beneficial effects cited above, A. mangium may have a negative impact on ecosystems and biodiversity outside its native environment (Aguiar et al. 2014). In the current study, we have tried to find out why, besides its successful introduction in Arenosols of the Congolese coastal plains, the acacia trees died in the beginning of the second rotation of mixed-species plantation of acacia and eucalypt. The following hypothesis is formulated: A. mangium tree in the juvenile age of the second rotation will be less tolerant to drought conditions than are E. urophilla $x$ grandis trees.

\section{METHODS}

Studied site characteristics, trial history and soil analyses. The study site was a mixed plantation of acacia and eu- calypt located approximately $35 \mathrm{~km}$ East of Pointe-Noire city on a plateau close to the Tchissoko village in the Republic of Congo $\left(4^{\circ} \mathrm{S}, 12^{\circ} \mathrm{E}, 100 \mathrm{~m}\right.$ Alt.). The soil is a deep Ferralic Arenosol, overlaying geological bedrock of thick detritic layers (continental origin from Plio-Pleistocene). Soil fertility is low, with a low CEC $\left(<0.5 \mathrm{cmol}+\mathrm{kg}^{-1}\right)$, high sand content ( $>90 \%$ of mineral soil), very low clay and silt content ( 2 to $6 \%$ according to depth, respectively) and low iron oxides content $(<1.5 \%$ of the bulk soil, Mareschal et al. 2011). The climate is subequatorial with a cool dry season extending typically from May to September, with the mean annual rainfall of $1,250 \mathrm{~mm}$ and more than $85 \%$ of atmospheric moisture. The studied area was afforested in 1984 with eucalypt hybrids. Before the trial establishment, vegetation was native tropical savanna dominated by the poaceae Loudetia arundinacea (Hochst.) Steud.

A complete randomized block design was established in May 2004 with five blocks (first rotation). The first rotation of mixed-species plantation was planted with $E$. urophylla $x$ grandis hybrid and $A$. mangium with starter fertilization (ammonium nitrate, $43 \mathrm{~kg} \mathrm{ha}^{-1}$ of nitrogen). A pure acacia plot (100A), a mixed-species plot with $50 \%$ acacia and $50 \%$ eucalypt trees $(50 \mathrm{~A} 50 \mathrm{E})$ and a pure eucalypt plot $(100 \mathrm{E})$ were established within each block at a stocking density of 800 trees per hectare. Each plot $\left(1,250 \mathrm{~m}^{2}\right)$ consisted of an inner part of 36 trees $(6 \times 6)$ and two buffer rows (Epron et al. 2013). The second rotation was replanted under the same scheme as used in the previous rotation in March 2012 with E. urophylla x grandis hybrid and A. mangium with starter fertilization $\left(\mathrm{KCl}, 150 \mathrm{~kg} \mathrm{ha}^{-1}\right)$ (figure 1). Monitoring equipment such as Campbell CR 1000 was installed to collect data on rainfall and soil moisture. Soil water content was monitored with CS616 Campbell probe buried at various distances from the trees.

Soil sampling $(0-15 \mathrm{~cm})$ was completed in December 2011 (end of the first rotation at age 7 years) and in March

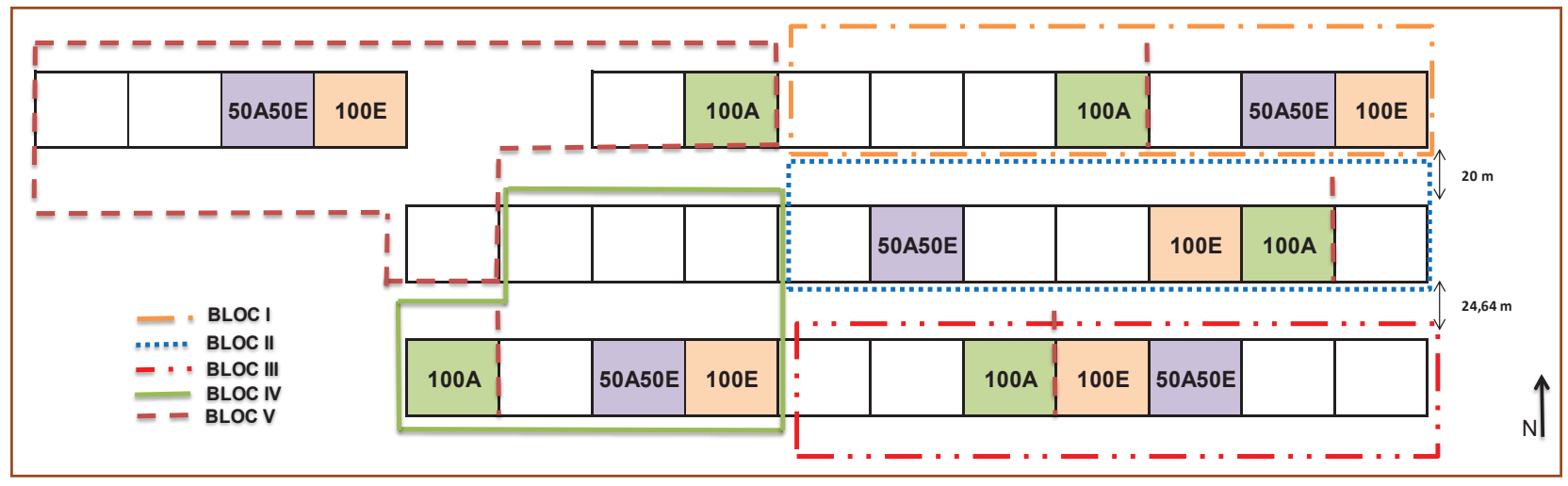

Figure 1. Tchissoko trial, total area: 4.375 ha. 100A: pure acacias; 50A50E: mixed, $50 \%$ acacia and $50 \%$ eucalypt hybrid. Prueba de Tchissoko, área total: 4.375 ha. 100A: acacias puras; 50A50E: mezclado, $50 \%$ de acacia y $50 \%$ de híbrido de eucalipto. 
2014 (at age two years of the second rotation) in three out of the five blocks in the inner part of the stands. A composite soil sample consisting of nine sub samples was collected for each of the three stands of the three blocks. The soil samples were air-dried and sieved at $2 \mathrm{~mm}$. Total carbon and nitrogen concentrations were determined by combustion with an elemental analyzer (NCS 2500, Thermoquest, Italy). The soil samples were fused with $\mathrm{LiBO}_{2}$ and dissolved in $1 \mathrm{~N} \mathrm{HNO}_{3}$. Mean total phosphorus (P), aluminium $(\mathrm{Al})$, iron (Fe) and manganese $(\mathrm{Mn})$ were analyzed using plasma atomic emission spectroscopy (ICP-AES, soil analyses laboratory, INRA, Arras, France).

\section{RESULTS}

Soil carbon and nitrogen concentrations at the end of this first rotation are summarized in table 1 . The studied soil has low nitrogen concentrations $(<0.07 \%)$ with a high $\mathrm{C} / \mathrm{N}$ ratio mainly in the upper layer soil. Phosphorous and calcium concentrations are also low (table 2). The dry season during 2013 was five months longer than that of 2012 (figure 2), while the soil water content down to a depth of 0.15 meters was higher in the pure eucalypt $100 \mathrm{E}$ stands than in the pure 100A acacia stands (figure 3 ). The damage of acacia trees was observed in the acacia stands early in March 2013, one year after the planting of the second rotation. At the beginning, leaves became ye-

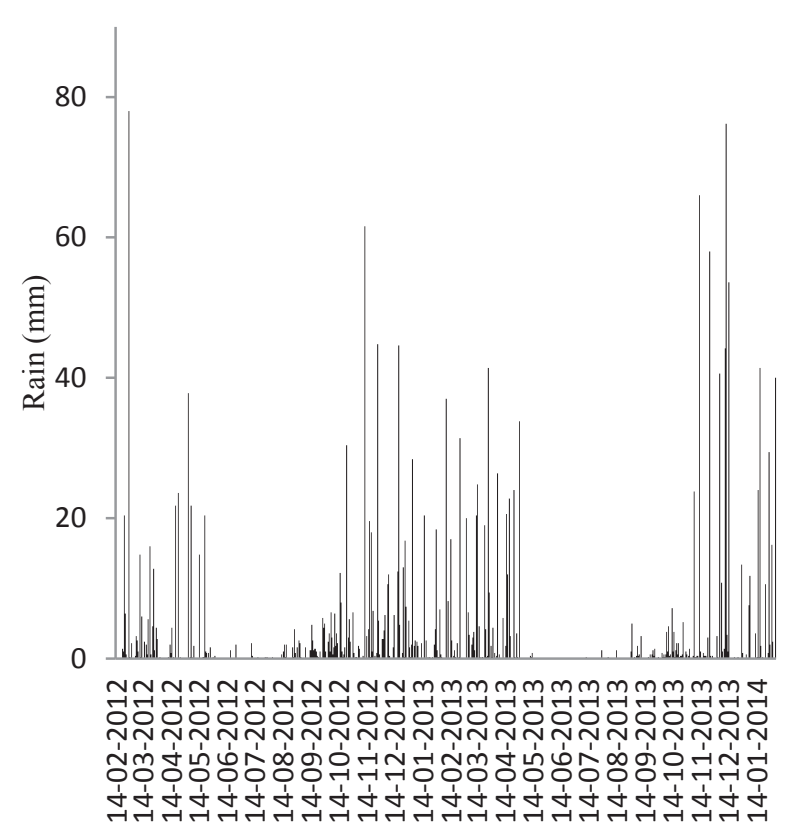

Figure 2. Precipitation at the studied site during two years and soil water contents down to 0.015 depth under 100A, 100E and 50A50E (Tchissoko, Republic of Congo).

Precipitación en el sitio estudiado durante dos años y contenido de agua del suelo hasta $0,015 \mathrm{~m}$ de profundidad bajo $100 \mathrm{~A}, 100 \mathrm{E}$ y 50A50E (Tchissoko, República del Congo).

Table 1. Nitrogen $(\mathrm{N})$, carbon $(\mathrm{C})$ concentrations and $\mathrm{C} / \mathrm{N}$ ratio to a depth of $0.15 \mathrm{~m}$ under the pure acacia (100A), $50 \%$ acacia and $50 \%$ eucalypt (50A50E) and pure eucalypt (100E) stands of the mixed species plantation of acacia and eucalypt at the end of the first rotation (mean with standard error adapted from Koutika et al. 2014).

Concentraciones de nitrógeno $(\mathrm{N})$, carbono $(\mathrm{C})$ y relación $\mathrm{C} / \mathrm{N}$ hasta una profundidad de $0,15 \mathrm{~m}$ bajo los rodales de acacia pura (100A), $50 \%$ acacia y $50 \%$ eucalipto $(50 \mathrm{~A} 50 \mathrm{E})$ y eucalipto puro (100E) en las plantaciones de especies mixtas de acacia y eucalipto al final de la primera rotación (media con error estándar adaptado de Koutika et al. 2014).

\begin{tabular}{cccc}
\hline $\begin{array}{c}\text { Depth and soil properties } \\
\text { (soil collected on December 2011) }\end{array}$ & $\mathrm{N}(\%)$ & $\mathrm{C}(\%)$ & $\mathrm{C} / \mathrm{N}$ \\
\hline & 100A-A. mangium & & \\
\hline $0-0.05 \mathrm{~m}$ & $0.058(0.00)$ & $0.99(0.07)$ & $16.9(0.54)$ \\
$0.05-0.10 \mathrm{~m}$ & $0.041(0.00)$ & $0.59(0.03)$ & $14.2(0.45)$ \\
$0.10-0.15 \mathrm{~m}$ & $0.038(0.00)$ & $0.40(0.01)$ & $10.6(0.26)$ \\
\hline & 50A50E-50 \% acacia and 50\% eucalypt & \\
\hline $0-0.05 \mathrm{~m}$ & $0.064(0.00)$ & $1.18(0.08)$ & $17.8(0.48)$ \\
$0.05-0.10 \mathrm{~m}$ & $0.042(0.00)$ & $0.56(0.02)$ & $13.3(0.35)$ \\
$0.10-0.15 \mathrm{~m}$ & $0.035(0.00)$ & $0.42(0.01)$ & $12.0(0.23)$ \\
\hline & $100 \mathrm{E}-$ eucalypt & & $17.1(0.51)$ \\
\hline $0-0.05 \mathrm{~m}$ & $0.050(0.00)$ & $0.87(0.09)$ & $13.0(0.56)$ \\
$0.05-0.10 \mathrm{~m}$ & $0.038(0.00)$ & $0.49(0.03)$ & $12.0(0.26)$ \\
\hline
\end{tabular}


Table 2. Phosphorus (P), aluminium (Al), iron (Fe), calcium (Ca) and manganese (Mn) in 0-0.05 m layer of stands 100A, 50A50E and 100E.

Fósforo (P), aluminio (Al), hierro (Fe), calcio (Ca) y manganeso (Mn) en una capa de 0-0,05 m de los rodales 100A, 50A50E y 100E.

\begin{tabular}{cccccc}
\hline $\begin{array}{c}\text { Treatments and } \\
\text { stands }\end{array}$ & $\begin{array}{c}\mathrm{P} \\
\mathrm{g} / 100 \mathrm{~g}\end{array}$ & $\begin{array}{c}\mathrm{Al} \\
\mathrm{g} / 100 \mathrm{~g}\end{array}$ & $\begin{array}{c}\mathrm{Fe} \\
\mathrm{g} / 100 \mathrm{~g}\end{array}$ & $\begin{array}{c}\mathrm{Ca} \\
\mathrm{g} / 100 \mathrm{~g}\end{array}$ & $\begin{array}{c}\mathrm{Mn} \\
\mathrm{g} / 100 \mathrm{~g}\end{array}$ \\
\hline & & Year 1-End of rotation 1 & & \\
\hline $100 \mathrm{~A}$ & 0.07 & 1.08 & 1.06 & - & 51 \\
$50 \mathrm{~A} 50 \mathrm{E}$ & 0.04 & 1.04 & 0.99 & - & 47. \\
$100 \mathrm{E}$ & 0.07 & 0.99 & 1.03 & - & 45 \\
\hline & & Year 2-End of rotation 2 & & \\
\hline $100 \mathrm{~A}$ & 0.01 & 0.99 & 0.97 & 0.09 & 49 \\
$50 \mathrm{~A} 50 \mathrm{E}$ & 0.06 & 1.02 & 0.94 & 0.06 & 45 \\
$100 \mathrm{E}$ & 0.03 & 0.97 & 0.98 & 0.13 & 45 \\
\hline
\end{tabular}

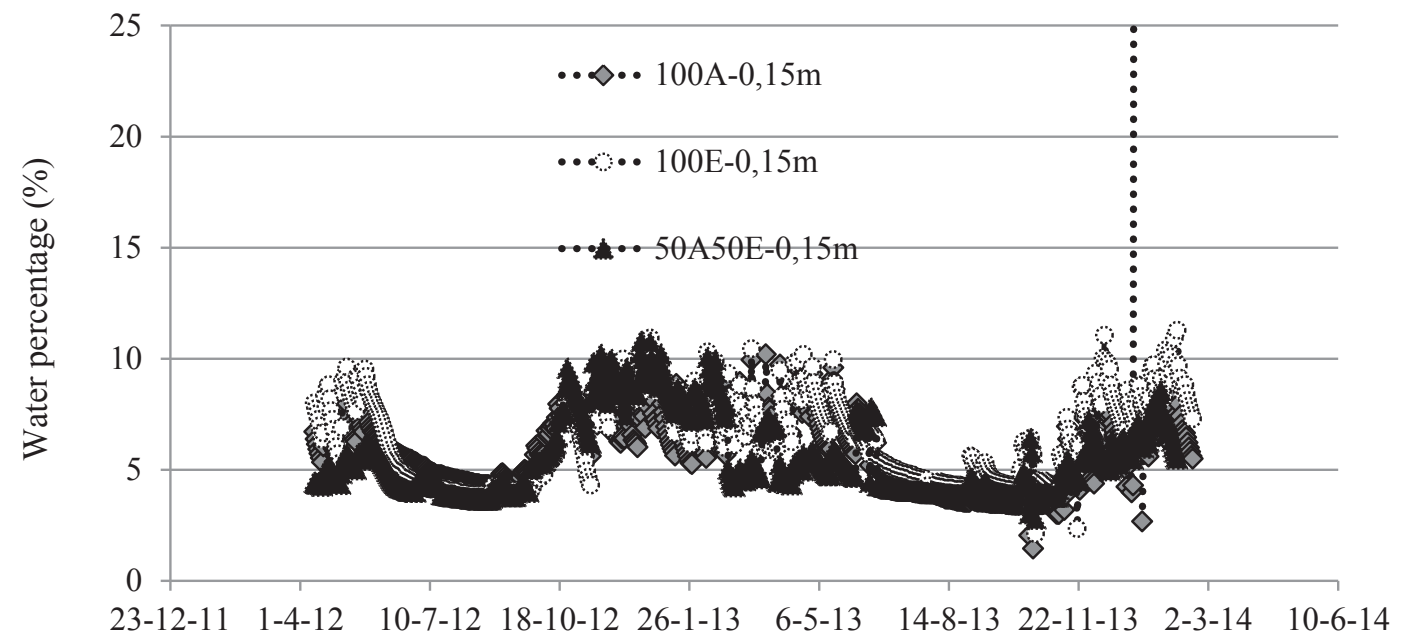

Figure 3. Soil water contents down to $0.015 \mathrm{~cm}$ depth under 100A, 100E and 50A50E.

Contenido de agua del suelo hasta una profundidad de $0,015 \mathrm{~m}$ bajo $100 \mathrm{~A}, 100 \mathrm{E}$ y $50 \mathrm{~A} 50 \mathrm{E}$.

llow followed by dark and brown stains on branches and stems. Around fifteen days later, the stem became black, followed by the drying up and death of the whole tree. The number of acacias impacted by the damage drastically increased during the subsequent five months, through $\mathrm{Au}-$ gust 2013.

Afterwards, branches were pruned up to $1.30 \mathrm{~m}$, leaving the trees at a ground height around $4 \mathrm{~m}$. Upper damaged branches were even pruned over 1.30 meters. After pruning, no sign of damage was further noticed and thereafter. The number and percentage of dead acacia trees in the pure acacia (100A) and $50 \%$ acacia and $50 \%$ eucalypt (50A50E) are reported in table 3. The biomass of wood, bark, leaves and branches of all stands at 12 and 24 months of plantation are presented in table 4 .
Table 3. Number and percentage of dead acacia trees in the pure acacia (100A), $50 \%$ acacia and $50 \%$ eucalypt (50A50E) of the mixed-species stands in the Congolese coastal plains. Values in brackets are percentages. Total tree number in the stand $=140$.

Número y porcentaje de acacias muertas en los rodales de acacia pura (100A) y $50 \%$ acacia y $50 \%$ eucalipto (50A50E) en las llanuras costeras congoleñas. Los valores entre paréntesis son porcentajes. Número total de árboles en el rodsl $=140$.

\begin{tabular}{ccc}
\hline Blocks and stands & $100 \mathrm{~A}$ & $50 \mathrm{~A} 50 \mathrm{E}$ \\
\hline Block I & $16(11.4 \%)$ & $4(2.9 \%)$ \\
Block II & $32(22.9 \%)$ & $1(0.7 \%)$ \\
Block III & $0(0 \%)$ & $0(0 \%)$ \\
Block IV & $1(0.7 \%)$ & $3(2.0 \%)$ \\
Block V & $0(0 \%)$ & $1(0.7 \%)$ \\
\hline
\end{tabular}


Table 4. Biomass of wood, bark, leaves and branches at 12 and 24 months in the pure acacia (100A), eucalypt (100E) and mixedspecies $(50 \mathrm{~A} 50 \mathrm{E})$ stands. There are means $( \pm$ standard error) in five blocks. For each year and tree part, different letters indicate significant differences between stands (HSD-test of Turkey) and ANOVA at $5 \%(*), 1 \%(* *)$ or 0.1 (***), (ns); adapted from Tchichelle (2016).

Biomasa de madera, corteza, hojas y rama a los 12 y 24 meses en rodales de acacia pura (100A), eucalipto (100E) y especies mixtas (50A50E). Medias ( \pm error estándar) en cinco bloques. Para cada año y parte del árbol, diferentes letras indican diferencias significativas entre los rodales (prueba HSD de Turkey) y ANDEVA al $5 \%(*), 1 \%(* *)$ o $0,1(* * *)$, (ns); adaptado de Tchichelle (2016).

\begin{tabular}{|c|c|c|c|c|c|}
\hline \multirow{2}{*}{ Months } & \multirow{2}{*}{ Component } & \multicolumn{4}{|c|}{ Aboveground biomass $\left(\mathrm{kg} \mathrm{m}^{-2}\right)$} \\
\hline & & $100 \mathrm{~A}$ & $50 \mathrm{~A} 50 \mathrm{E}$ & $100 \mathrm{E}$ & Significance \\
\hline \multirow{5}{*}{12} & Wood & $0.15 \pm 0.01 \mathrm{a}$ & $0.12 \pm 0.02 \mathrm{ab}$ & $0.08 \pm 0.01 b$ & $* *$ \\
\hline & Bark & $0.06 \pm 0.00 \mathrm{a}$ & $0.04 \pm 0.01 \mathrm{~b}$ & $0.02 \pm 0.00 \mathrm{c}$ & $* * *$ \\
\hline & Leaves & $0.30 \pm 0.01 \mathrm{a}$ & $0.18 \pm 0.02 b$ & $0.08 \pm 0.00 \mathrm{c}$ & $* * *$ \\
\hline & Branch & $0.20 \pm 0.01 \mathrm{a}$ & $0.14 \pm 0.02 b$ & $0.08 \pm 0.01 \mathrm{c}$ & $* * *$ \\
\hline & All & $0.70 \pm 0.04 \mathrm{a}$ & $0.48 \pm 0.05 \mathrm{~b}$ & $0.25 \pm 0.02 \mathrm{c}$ & $* * *$ \\
\hline \multirow{5}{*}{24} & Wood & $0.82 \pm 0.08$ & $0.99 \pm 0.06$ & $0.87 \pm 0.09$ & ns \\
\hline & Bark & $0.23 \pm 0.02$ & $0.23 \pm 0.01$ & $0.18 \pm 0.02$ & ns \\
\hline & Leaves & $0.67 \pm 0.06 \mathrm{a}$ & $0.54 \pm 0.03 \mathrm{a}$ & $0.19 \pm 0.01 b$ & $* * *$ \\
\hline & Branch & $0.91 \pm 0.08 \mathrm{a}$ & $0.77 \pm 0.05 \mathrm{a}$ & $0.36 \pm 0.07 \mathrm{~b}$ & $* * *$ \\
\hline & All & $2.63 \pm 0.25 \mathrm{a}$ & $2.54 \pm 0.15 \mathrm{a}$ & $1.60 \pm 0.19 b$ & $* *$ \\
\hline
\end{tabular}

\section{DISCUSSION}

Even though pruning acacia trees may sometimes contribute to fungi wound infection, careful pruning reduces this risk in young $A$. mangium plantations (Tarigan et al. 2011). Therefore, to stop the damage of acacia trees in the mixed species plantation with eucalypts located in the Congolese coastal plains and based on the findings of Beadle et al. (2007), it was decided to make the pruning of acacia trees in both 100A and mixed-species 50A50E stands, where the damaged trees have been first observed. After pruning, the damaged acacias performed better and no further damage was identified in any additional trees during the following weeks. This result confirmed the hypothesis i.e., acacia tree is less tolerant to drought conditions than are E. urophilla $x$ grandis trees at the juvenile age of the second rotation of the mixed species plantation. It appears that the rain season, which began in October 2013, may have stabilized the outbreak of the acacia tree damage. It also appears that the damage of acacia tree was not due to any fungal pathogens as observed in other parts of the world (Maguias et al. 2011), as no additional outbreak has been observed after pruning.

It may be assumed that acacia tree damage, observed in the pure 100A and mixed-species 50A50E stands of the plantation, may have been due to the extended dry season occurring from May to September 2013 compared with the previous shorter 2012 season (July-September), which lasted only from June to September. The impact of drought on the young plantation can also be observed through the measured precipitation and soil water content to a depth of 0.15 meters (with the lower soil water content in the pure $100 \mathrm{~A}$ and the higher in the pure eucalypt 100E). It is important to notice that the higher percentage of damaged acacia trees observed in the 100A stands at the juvenile age of mixed-species plantation located in the Congolese coastal plains (table 3 ) did not negatively impact the aboveground biomass. As a nitrogen fixing species, A. mangium did positively affect aboveground biomass as revealed by its higher estimated wood and bark biomass in $100 \mathrm{~A}\left(0.15 \mathrm{~kg} \mathrm{~m}^{-2}\right.$ and $0.06 \mathrm{~kg} \mathrm{~m}^{-2}$, respectively) relative to $100 \mathrm{E}\left(0.08 \mathrm{~kg} \mathrm{~m}^{-2}\right.$ and $0.02 \mathrm{~kg} \mathrm{~m}^{-2}$, respectively) (table 4 , Tchichelle 2016).

The drought may have triggered the damage of the acacia trees in the young plantation in the beginning of the second rotation, enhanced by the poor-nutrient status and coarse texture of soil. These observations are supported by Laclau et al. (2013) who found at the Itatinga Experimental Station, state of Sao Paulo in Brazil, that the pure A. mangium stand $100 \mathrm{~A}$ developed a higher number of fine roots in the first two meters than those developed by the mixed species stand 50A50E. The shallow superficial root system may also explain why the A. mangium is prone to drought, which further involves tree damage in the juvenile age of acacia and eucalypt plantation at the second rotation. Fortunately, the damage of acacia trees occurred in the juvenile age of the plantation did not have a negative impact on the biomass of the wood, bark, leaves and branches (table 4). 


\section{CONCLUSIONS}

Tree acacia damage due to an extended dry season, and enhanced by a shallow root system in a sandy soil, may be alleviated through gentle pruning. The observed acacia damage was more pronounced in the pure acacia (100A) and less in the mixed eucalypt stands (50A50E), and may suggest that $A$. mangium is less tolerant to drought conditions than are eucalypt trees in the juvenile age of the rotation. This damage of acacia trees occurred at the juvenile age of the mixed-species plantations of acacia and eucalypt, and did not have, however, a negative effect on aboveground biomass at 12 and 24 months. This observation is critical for the establishment of acacia plantations in the coastal plains of Congo and surrounding regions, where annual precipitation can be $750 \mathrm{~mm}$ lower than it is in their native ecosystem and the dry season may be longer. However, more elaborated studies must be conducted to confirm this observation.

\section{ACKNOWLEDGMENTS}

The authors thank Dr. Heidi Peterson (Minnesota State University, US) for editing and staff of CRDPI for the pruning and fieldwork. This paper is dedicated to Sonia Rudowsky ( $\dagger$ ), who passed away at the end of December 2015, after a traffic accident in Pointe-Noire, Republic of the Congo.

\section{REFERENCES}

Aguiar Jr M, RI Barbosa, JBF Barbosa, Jr M Mourao. 2014. Invasion of Acacia mangium in Amazonian savannas following planting of forestry. Plant Ecology and Diversity (1-2):359-369.

Beadle C, K Barry, E Hardiyanto, R Junarto Irianto, C Mohammed, A Rimbawanto. 2007. Effect of pruning Acacia mangium on growth, form and heart rot. Forest Ecology and Management 238:261-267.

Binkley DC, C Giardina, MA Bashkin. 2000. Soil phosphorus pools and supply under the influence of Eucalyptus saligna and nitrogen-fixing Albizia facaltaria. Forest Ecology and Management 128(3): 241-247.

Bouillet JP, JP Laclau, JLMGonçalves, M Voigtlaender, J Gava, FP Leite, R Hakamada, L Mareschal, A Mabiala, F Tardy, J Levillain, P Deleporte, D Epron, Y Nouvellon. 2013. Eucalyptus and Acacia tree growth over entire rotation in single- and mixed-species plantations across five sites in Brazil and Congo. Forest Ecology and Management 301:89-101.

Coetzee MPA, Wingfield BD, Golani GD, Tjahjono B, Gafur A,
Wingfield MJ. 2011. A single dominant Ganoderma species is responsible for root rot of Acacia mangium and Eucalyptus in Sumatra. Southern Forests 73(3-4):175-180.

Cole TG, RS Yost, R Kablan, T Olsen. 1996. Growth potential of twelve Acacia species on acid soils in Hawaii. Forest Ecology and Management 80:175-186.

Epron D, Y Nouvellon, L Mareschal, RM Moreira, LS Koutika, B Geneste, JS Delgado-Rojas, JP Laclau, G Sola, JLM Gonçalves, JP Bouillet. 2013. Partitioning of net primary production in Eucalyptus and Acacia stands and in mixedspecies plantations: two case-studies in contrasting tropical environments. Forest Ecology and Management 301:102111.

Eyles A, C Beadle, K Barry, A Francis, M Glen, C Mohammed. 2008. Management of fungal root-rot pathogens in tropical Acacia mangium plantations. Forest Pathology 38:332-355.

Inagaki M, K Kamo, K Miyamoto, J Titin, L Jamalung, J Lapongan, S Miura. 2011. Nitrogen and phosphorus retranslocation and N:P ratios of litterfall in three tropical plantations: luxurious $\mathrm{N}$ and efficient $\mathrm{P}$ use by Acacia mangium. Plant and Soil 341(1-2): 295-307.

Koutika LS, D Epron, JP Bouillet, L Mareschal. 2014. Changes in $\mathrm{N}$ and $\mathrm{C}$ concentrations, soil acidity and $\mathrm{P}$ availability in tropical mixed acacia and eucalypt plantations on a nutrient-poor sandy soil. Plant and Soil 379:205-216.

Laclau JP, Y Nouvellon, C Reine, J L de Moraes Gonçalves, A V Krushe, C Jourdan, G le Maire, JP Bouillet. 2013. Mixing Eucalyptus and Acacia trees leads to fine root over-yielding and vertical segregation between species. Oecologia 172:903-913.

Máguas C, KG Rascher, A Martins-Loucçao, P Carvalho, P Pinho, M Ramos, O Correia, C Werner. 2011. Responses of woody species to spatial and temporal ground water changes in coastal sand dune systems. Biogeosciences 8:3823-3832. DOI:10.5194/bg-8-3823-2011.

Mareschal L, JDD Nzila, MP Turpault, AT M'Bou, JC Mazoumbou, JP Bouillet, J Ranger, JP Laclau. 2011. Mineralogical and physico-chemical properties of Ferralic Arenosols derived from unconsolidated Plio-Pleistocenic deposits in the coastal plains of Congo. Geoderma 162:159-170

Tarigan M, MJ Wingfield, M van Wyk, B Tjahjono, J Roux. 2011. Pruning quality affects infection of Acacia mangium and $A$. crassicarpa by Ceratocystis acaciivora and Lasiodiplodia theobromae. Southern Forests 73(3-4):187-191.

Tchichelle SV. 2016. Production de biomasse et quantification des flux d'azote dans une plantation mixte d'Eucalyptus urophylla $x$ grandis et d'Acacia mangium au Congo. Thèse Université de Lorraine, France. 92 p.

Yamashita N, S Ohta, A Hardjono. 2008. Soil changes induced by Acacia mangium plantation establishment: Comparison with secondary forest and Imperata cylindrica grassland soils in South Sumatra, Indonesia. Forest Ecology and Management 254:362-370. 